\title{
SYLVIA TOWNSEND WARNER'S LETTERS TO SAMUEL MENASHE
}

Born in 1925 in New York, the city where he has lived most of his life since graduating from the Sorbonne in 1950, Samuel Menashe has become master of the brief poem; compressed, lucid and direct. Known to the cognoscenti, he is however part of no recogniseable school, nor is his work 'fashionable'. This and his meagre output helps explain his relative obscurity, although his second volume, No Jerusalem But This (1971), brought praise from Stephen Spender for 'language intense and clear as diamonds'.

As an aspiring young poet in search of a publisher Menashe approached several established poets, Sylvia among them. In her generous way, she recommended him to Victor Gollancz who later published his first volume The Many Named Beloved (1961). In this way their friendship began and though Menashe made the journey to Dorset for one long weekend, it wás largly an epistolatory affair which ebbed and flowed from 1960 until Sylvia's death in 1978. Some twenty or so of her letters to him, mostly from her last decade and his most prolific - three of his volumes were published in the early ' 70 s - are held in the Berg Collection of the New York Public Library.

Together they provide a touching portrait of Sylvia in her final years dispensing advice when required, at times reluctantly, on the young poet's work, but always full of encouragement for one whose talent she clearly recognised. The letters also contain several short, unpublished offerings that were Sylvia's contribution to the kind of exchange that 
often takes place between poets who have become friends.

Menashe's collected works appeared three years after the publication of Sylvia's own Collected Poems (1982).

Jay Barksdale \& Peter Tolhurst

$14: x i: 1960$

Dear Mr. Menashe,

I have just come back from a short holiday to find a letter from Victor Gollancz telling me that he is taking your poems. I am most sincerely glad. I send you my congratulations for now \& my best wishes for the future.

V.G.'s letter enables me to write to you. I have been feeling very worried that I did not thank you for the copies you sent me. But you sent them without your address, \& though I had scribbled down from our telephone conversation, when I came to look for it, it was mislaid.

Learn from this near mishap that writers should always give their address. However, now I can be sure of finding you through Gollancz.

Very sincerely

Sylvia Townsend Warner

$30: i x: 1960$

Dear Mr. Menashe,

Thank you very much for letting me see these poems. They have given me great pleasure, especially 'November' for its competence, \& 'There is no Jerusalem but this' for the energy of thought and the animal grace of expression. Both these are complete and achieved there is no doubt about them. But the poem that made the sharpest impression on me is 'April'. Not as a whole, not as a successful statement - there is a certain fumbling and falseness of language in the 2-5 lines. But that 
sudden swallow-flight to Norway, a landscape ... intensely exciting, unforeseen, infallibly right; and convinces me that you are a true poet, with the true marrow in your bones.

Yours sincerely

Sylvia Townsend Warner

Christmas 1960

And after all the common Kings

Who brought their common envied wealth

Came one as if by stealth

And laid a poem at her side

$25:$ viii $: 1961$

Dear Samuel Menashe,

You can have no idea how difficult I find it to do anything so formal as to write to you about your poems. My impulse is to say, Look! As one does when a butterfly flits past ... But I can scarcely draw your attention to your own poetry.

I rather wish I could for then you could see it, as for the first time, and without the creative anxiety which gets between us and our creations. I do assure you, you would be both impressed and delighted.

It is such a long time since poems [have] been silent. They yell, stamp, foray, rattle bones... Yours are as silent as flowers and fruit. The apple has nothing to say; it is an apple. The silence of your poems mark you as someone who has no need to proclaim, no reason to assert.

I thank you \& wish you well with all my heart.

Yours sincerely

Sylvia Townsend Warner 
$1:$ iv $: 1970$

Dear Samuel Menashe,

It was a great pleasure to find your poem in the $\mathrm{New}$ Yorker. A greater pleasure to know in a flash that it was yours, as infallibly as one recognizes a particular gleam of a kingfisher.

Yours sincerely

Sylvia Townsend Warner

$26: i v: 1971$

Dear Samuel Menashe,

Thank you for No Jerusalem But This. You know how much I admire your poems. I need not reiterate. But I gain (these unchanged, I expect) by having so many in a book; as jewels are most jeweled when they lie in their naked integrity in a bowl, to be turned and sifted, possessed and free, themselves and unenslaved to [salvation]. I would never turn aside from reading them to consider which I like best. It is your poems that I enjoy and the mind they came from - and the kindness which sent them to me.

Some you have sent to me already. And I must have seemed bleak and ungrateful not to thank you. But the last years have been captivity. In 1968 Valentine Ackland, who was more real and much more dear to me than myself, developed cancer. In the autumn of 1969 she died and I have been alone and a ghost since.

'The Bare Tree' tells me something of my own bereavement; and that you will understand and sympathise.

Be fruitful and multiply

Sylvia Townsend Warner 
$16: v: 1971$

Dear Samuel,

I was right to turn to you. Your image of the river and the water-wheel has done deeper than comfort; it has filled me. It has been in my mind all day. I shall wake to it tomorrow and morrow after morrow. That is what it is to be a poet. I knew you a poet when I wrote to Gollancz ten years ago. A better poet by ten years now, as I saw when you sent me the naked version of 'April'.

Within a few days I shall be writing to William Maxwell of the New Yorker. They are all shut in cages \& categorized there, but he is not a natural captive, so I will remind him of Louise Bogan and tell him that she (I too) would wish your new poems to be reviewed. Have you an English publisher yet?

Next month I shall be seeing Benjamin Britten who reads a great deal of poetry, and I shall take No Jerusalem with me to Aldeburgh. To be set to music like his is a kind of review; at any rate, a recognition.

I am too old and private to have much pull. But what I can do, be sure I will. Have you invoked Kathleen Raine? She is somewhat of a prig, but influential.

Yours sincerely

Sylvia

I have asked Viking to send you a copy of my last short stories. I like the green torso myself.

$26:$ vii $: 1971$

Dear Samuel,

My book was out long ago \& Viking told to send you a copy. Curse them. Jerusalem is with Peter Pears who will show it to Ben Britten when the dust of the Aldeburgh festival 
has settled and Ben can turn his mind to composing. I have also given a copy (you wisely send me two) to another composer called Alan Bush. He is a good composer though not so imminent as Ben. I think he would be glad of a new poet to set. He takes poetry seriously and has an ear for it.

I return your review; which pleased me as I hope it pleased you. I particularly dislike the word 'miniscule' - but even so it pleased me. I would not call a bullet miniscule, myself.

Yours

Sylvia

New Year's Eve, Old Year's Night [1972].

Learning to walk the child totters between embraces, Admiring voices confirm its tentative syllables:

In the day of unlearning speech, mislaying balance,

We make our way to the grave, delighting nobody.

So the wheel turns in the bright implacable river.

Dear Samuel, I do not forget to think of you, be glad of you, \& wish you well.

Sylvia

$28: i: 1973$

Dear Samuel,

I have taken time to answer your letter because I was taking time to consider your alterations. I think almost is much better than nearly: it carries a sense of journey's end; 'almost-there', for instance. And lines 5, 6, 7, yes, admirable. But I am discontented with the last line. Compels is such a weak assonanice for melt .... 'Where probe compelled' would be better for sound, and for effect, so I feel, because the poem demands a sharp, positive close. And 'uniform' seems to be a 
better title than 'the probe'. 'The Uniform' is more operative, it wields the probe by virtue of being a uniform.

It is one of your flint arrowhead poems.

Your departure left me feeling flat and cold: you had brought such fire and reality into the house; some remained, but the torch was gone.

And since then the news has guttered from bad to worse.

You will know how I feel.

Ursula Vaughan Williams's name was considerably the most influential of those I have sent you. It is excellent that she should be the first one to write to you - even if she is foxed by your brevity. Her own poems are rather 'white-tie', but she writes seriously and sometimes with dazzling sincerity.

Sleet strikes on my window; an imperfectly developed snow. There will be snow on the mounts across your lake.

Love

Sylvia

$21:$ viii $: 1973$

Dear Samuel

How very pleasant to know that another book of your poems is in the offing; and that you are in London. Indeed, we must meet. I shall be in London between trains on September 14th, we could meet \& kiss on a platform. But better still, can you come here for the week-end before? 7 th to the 10th or a mid-week if your week-ends are booked up.

The house is quiet, \& full of books, and I am a fair cook \& a very impressive hostess. And I should be delighted to see you here.

Love

Sylvia 
28 : xii: 1973

Dear Samuel,

Your letter (postcard) came this morning, written on the day you were flying to Israel. I was excited as though I was flying there myself - for a moment, for one of those rainbowbubbled moments when one's emptiness reflects all the colours of peacocks.

There could be no nobler place ... to begin the New Year, among all that honour \& mourning and defiance: and subtlety. 'The serpent was more subtle than all the beast of the field.' The serpent was certainly the first Jew.

I like to think that Valentines' poems are remembered in Israel; proud to think that I am. Perhaps you will settle there? If you do, I will come to visit you.

Love

Sylvia.

$12: i: 1974$

Dear Samuel

The packets of polenta came. I cooked some immediately. It was delicious and transported me to Italy to vineyards \& cypresses and the smell of fruit \& the clutter of markets.

But even before I got to the polenta, the parcel transported me - to an earlier Italy. The seal on the string was so massive that I felt it had come from ancient Rome, that a senator had stamped it. Thank you very much, dear Samuel.

How are you? Some day you will tell me your experiences, your impressions. My spirit droops at the news - droops in shame. We are behaving so vilely, so treacherously. ... I hope it is not always true that countries get the governments they deserve. I know we do not deserve our Heath, or $M$. Pompidou, whom he lackeys. 
Love

Sylvia

$19:$ iv $: 1974$

On the heels of Easter when the Sun dances

To flute of birds \& thrum of sap rising

Comes the bitter surprise, the blackthorn winter,

When hailstones clatter \& skies darken,

And the lamb forlorn

Cries out, why was I born?

Dear Samuel, how are you, and where?

Love Sylvia

$27:$ vii : 1974

Dear Samuel,

I was away when your book came; it had to wait here for me, singing to itself in an empty house. I opened it on 'Simon Says'; and the shock of such artless perfection stays with me \& I still feel it is the best poem in the book...only a hairsbreadth stands between it and silence.

It is an aching silence in 'Leah bribed Jacob'. Is it still the same? I feel as if you may have gone back to N.Y.C to sleep under a low door and ... a narrow room. I might - with a great many grains of salt - say it is good for me* to have been in trouble, but I can never say it for my friends.

I was sorry not to see you before you went back, but France is so ample, so honestly lovely, that I reconciled myself knowing you were at ....I shall see you again.

Sylvia

* It was dubiously good, anyway. 
$13: x: 1974$

Dear Samuel,

I expect you are back in N.Y.C. by now. The noise of a city is not so brutal as of bulldozers; there is a texture of purpose in it.

Thank you for the two poems. 'Loss' is perfect as a seashell ... the same strict contours. Here am I, a poem I woke up with, one timeless dark midnight.

Each night I say

I might die before day.

Why must my fate interpose

This tedious cadenza

Between my music and its close?

Would I were away!

Love to you

Sylvia

$22: x i i: 1974$

Dear Samuel,

You need a listner. Since I can't send myself, I shall post you, early in the New Year, a photograph Valentine took of me, which is the only good likeness since the childphotograph she had buried with her ashes.

You are middle-aged, I am old. We are in much the same boat (except that $I$ shall disembark sooner). One cannot grow out of a loss, one cannot grow round it. The only expedient is to grow with it. For the loss perishes, develops, amplified. It amplifies itself and it fills itself. It is the third year since Valentine's death and I know her better than I did then - more completely, more comprehendingly. ...

Your mother with her precise nose is so real to me through your poems that I know a great deal of what you will tell me my proxy, my picture. Through you, I feel a deep love for her, 
a reverence \& a companionship of mind. I love her spiritual shrewdness, her exactitude of mind, her faithfulness to truth sans ornament, sans abuse or denial. I love her steady giving, and her sudden fits. These are echoed in the 'wonderful temporary from pain' you speak of. In this sense, loss is an enlargemet of love.

And do not try too hard, do not struggle to change your life. Your life changed when she died: you still have to adapt yourself to the change which has taken place in you.

For meeting was part of that adaptation. I am glad we met.

Love

Sylvia

$17:$ iii $: 1975$

Dear Samuel,

I am sorry about your John's illness \& the long anxiety and distress of your winter. I hope at any rate you had the comfort of being able to stand by him - not stand at an imposed distance.

When cancer was killing Valentine I was able to be with her. That sad companionship, \& her courage remain in my mind as a something - the last thing - partaken. That was more than five years ago; and I am still nailed to my longevity, and decay alive, and am wonderful for my age.

Thank you for your 'March' poem. This year was all mud \& flood till a couple of days; \& now a north wind and a yard frost has blown every ... from the face of the earth, ...

Affectionately

Sylvia 
$18: v: 1975$

\section{Equivalence of Creation}

Fish come solid

Out of the sea,

Each with its due weight of majesty.

The purposed sprat

Knows what it would be at,

And the skate,

Twirling in its death-agony,

Is the embodied

Wave which flopping down

On the fisherman's cobble has left him to drown.

How are you, dear Samuel?

Love

Sylvia

$1:$ vii $: 1976$

Dear Samuel

I will bear in mind the good advice in Scissors, and try to live up to it - when it is cooler. We are all shriveling in a draught. There has been no rain since early April, and I am worn out with decanting my bathwater into cans and staggering around the garden, deciding whether I will vist beans with mercy, or courgettes, for there isn't enough mercy for the both. I am glad I am not God.

I have been reading a book by Arthur Koestler, called The Thirteenth Tribe. The Thirteenth Tribe were the Khazars, pastoral bandits in Caucasia. Poised between Muslims and Byzantium, they fled for Judaism, and according to Koestler, were the founding fathers of Polish Jewry.

I am glad California wasn't as bad as you anticipated. 
Things seldom are. It is the mild sleepy woollen dogs who bite one to the bone.

Love

Sylvia

$6:$ ii : 1978

Dear Samuel,

I wish I could fittingly retort to your page of small poems. I am posting you a collection of mine, with a few short ones among them - the best I can do (this was made for my 'morning' at the Aldeburgh Festival this summer).

Please keep well, and go on with poems, \& look as splendid as ever. I often remember how you came here, and what pleasure it gave me to observe your Jewish pride.

And I wish you well free from your encumbrance. I am old, and shall soon die. I know how important it is to die free and unfastened by former strings.

Yours sincerely

Sylvia Townsend Warner

Transcription of a holograph poem, signed, undated

Experimentally poking the enormous

Frame of the universe

This much we know:

It has a pulse - like us.

But if it lags for woe,

Quickens for fever

Or calm euphoria measures it for ever

Further astronomers must show. 
for

Samuel Menashe

with best wishes

from

Sylvia Townsend Warner

Undated postcard

(The Hedge Warbler from a wood engraving by Th. Bewick)

The threadbare woods are still,

The field smooth - snowed and sly.

Puffed out against the cold.

The bird tightens his hold

On the dead bough, sharpens his shrill

Flame of defiance to the freezing sky,

As though he were the last bird left alive.

with love \& best wishes from

Sylvia to Samuel. 